\title{
Intensification of the contact clarifiers work during the drinking water preparation
}

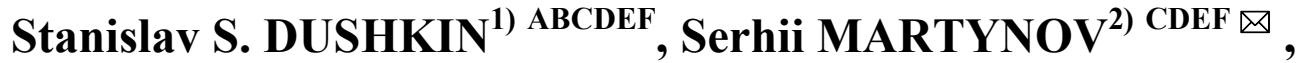 \\ Stanislav S. DUSHKIN ${ }^{3)}$ ABCE
}

\footnotetext{
1) orcid.org/0000-0003-4655-6197; O.M. Beketov National University of Urban Economy in Kharkiv, Ukraine; e-mail: d.akass@ukr.net

2) orcid.org/0000-0001-6790-8900; National University of Water and Environmental Engineering, str. Soborna 11, 33000, Rivne, Ukraine; e-mail: serhiym26@gmail.com

3) orcid.org/0000-0002-9345-9632; O.M. Beketov National University of Urban Economy in Kharkiv, Ukraine; e-mail: stanislav.dushkin@kname.edu.ua
}

For citation: $\quad$ Dushkin S.S., Martynov S., Dushkin S.S. 2019. Intensification of the work of contact clarifiers during the drinking water preparation. Journal of Water and Land Development. No. 41 (IV-VI) p. 55-60. DOI: 10.2478/jwld-2019-0027.

\begin{abstract}
In this paper we studied the intensification of the water clarification process on contact clarifiers with quartz sand filtering bed, which was modified with a solution of aluminum sulphate coagulant. The modification of the quartz sand filtering bed was carried out by applying to the surface of grains of quartz sand solution of coagulant aluminum sulphate with different doses. Investigation of the electrokinetic potential of the filtering material (quartz sand) was carried out by the percolation potential method.

The influence of electrical properties (size and sign of the charge) of the filtering bed itself and suspended solids in the water on the filtration process was studied. The filter material - quartz sand used in contact clarifiers has a negative electric charge. When the electric charge of the particles decreases, that is, as the $\zeta$-potential decreases, the repulsive forces decrease and it the adhesion of particles becomes possible. This is the process of coagulation of the colloid. The forces of mutual gravity between the colloidal particles begin to predominate over the electric repulsive forces at the $\zeta$-potential of the system less than $0.03 \mathrm{~V}$.

Modification of quarts filtering bed with a solution of coagulant aluminum sulphate recommended for the purification of surface water allows: to intensify the process of water clarification, to reduce the consumption of reagents by $25-30 \%$, with the obtaining purified water of the required quality, to reduce the production areas necessary for reagent management of treatment facilities, and to reduce the cost of water treatment by $20-25 \%$.
\end{abstract}

Key words: aluminum sulphate, contact clarifier, filtering bed, intensification of purification, quartz sand, surface water purification, water filtration

\section{INTRODUCTION}

Human activity has a negative impact on the environment, including water resources, which leads to a significant pollution [HAMMOURI et al. 2015; JAWECKI et al. 2017; MŁYŃSKI et al. 2016]. Rational use of water resources in conditions of water shortage, deterioration of its quality is a complex scientific, technical, and economic problem [ŁABĘDZKI 2016]. Water has a significant social importance because the presence of sufficient amount of water of appropriate quality is one of the main factors of safe living conditions and sustainable development of the state [BENRABAH et al. 2016; BERGEL et al. 2017; MARZEC et al. 2017].

In technological schemes for the drinking water preparation, filter structures can be used as a second stage of clarifying in schemes with settling tanks or as clarifiers with the suspended solids (fast filters), or as the independ- 
ent constructions in schemes of non settling filtering (contact filters and clarifiers). Therefore, from the effectiveness of the filtering structures depend not only on the quality of the treated water, but also on its prime cost [EPOYAN et al. 2018]. As granular filter loading used natural and artificial materials such as quartz sand, haydite, expanded polystyrene, zeolite, etc. [ORLOV et al. 2016; POLYAKOV 2011; TATARI et al. 2016].

Clarification of water refers to one of the most famous and effective ways to remove suspended and colloidal substances from water. One can single out the following methods of intensification of the clarification process [VASYLENKO et al. 2010]:

- filtration in the direction of reducing the grain size of the filtering bed, as well as its enlargement with a simultaneous increase height of the bed with the aim of reducing the intensity of the increase of head loss through dispersal of contamination in the greatest possible volume (it's most successfully realized in contact clarifiers);

- application of various methods of water pre-treatment with the aim of increasing the density and strength retained impurities by the filter and more uniform their distribution in the thickness of the filtering bed;

- application for filtering bed of granular materials with high intergranular porosity and developed specific surface area.

Contact coagulation is essentially the phenomenon of coagulation in the granular layer, because the process carried out due to the contact of colloidal and suspended solids with the surface of grains of filtering bed [MINTS, KASTALSKIY 1984].

At modifying the quartz sand filtering bed, a change in the $\xi$-potential observed by the addition of ions having a positive charge, which destabilizes colloidal particles, which ultimately increases the efficiency of contact coagulation.

The process of contact coagulation can be intensified by increasing the hydraulic size of the coagulated impurities when water is treated with an activated coagulant solution [EPOYAN, DUSHKIN 2013; KULYKOV et al. 2009]. At the same time, the mesh structure of the gel that forms on the filtering bed surface is more structured which allows to improve the technological parameters of the work of contact clarifiers and ultimately to increase the efficiency of contact clarifiers.

Modification of the molecular structure of the surface of quartz grains of filtering bed increases the dirt-holding capacity and increases the productivity of structures. Coagulants can be used to modify filter loads. Modification of filtering bed will allow increasing the productivity of water treatment plants with minimum costs, to improve the quality of the filtrate and reduce the cost of water treatment and reduce the cost of water treatment by reducing the consumption of reagents and increasing the filtration rate. The principle of the method based on the increasing the adhesive ability of the filtering bed by method of processing it by reagent solution. The process of sticking particles of suspended solids usually with a negative charge occurs more intensively towards modified filtering bed, than not modified [DUSHKIN et al. 2002].
This work consider the quartz sand filtering bed, that modified by the aluminum sulphate coagulant, which allows to intensify the work of contact clarifiers, to reduce the consumption of reagents with obtaining the purified water of the required quality, to reduce the number of production areas, necessary for reagent farming of treatment facilities and, at the same time, the cost of water treatment is reduced [DUSHKIN et al. 2017].

\section{MATERIALS AND METHODS}

Usually use quartz sand, haydite etc. in water treatment systems as a filtering bed, which have a negative charge. Since colloidal and other contaminants that in clarified water are also negatively charged, then between them and the surface of grains of the filtering bed appear electrostatic repulsive forces that prevent the particles from adhesion. Processing of quartz sand with a coagulant solution of aluminum sulphate leads to the formation the polymer film on the surface of grains filtering bed, gives the grains the positive charge and thereby creates conditions for a more complete flow of water purification processes, which is confirmed by scientific works [DUSHKIN 2012; VEITSER et al. 1974]. However, the model of the installation given in Dushkin's work 2012 can be used for study the modification of quartz sand filtering bed only after it improvement, which is connected with the peculiarities of modelling the work of contact clarifiers and the need for adjustments the constructive-technological parameters of the installation.

Researches of the influence of the modification of quartz sand filtering bed by the solution of aluminum sulphate coagulant on the filtering parameters performed on a laboratory installation, using water from Seversky Donets River the qualitative characteristic of which given below:

- content of suspended solids $-20-25 \mathrm{mg} \cdot \mathrm{dm}^{-3}$;

- colour of water - 65-75 degrees platinum cobalt scale (PCS);

$-\mathrm{pH}-7.1-7.2$;

- total water hardness $-6.3-6.7 \mathrm{~mol} \cdot \mathrm{m}^{-3}$;

- alkalinity $-2.5-2.8 \mathrm{~mol} \cdot \mathrm{m}^{-3}$.

During the researches, a laboratory installation used (Fig. 1), which allows carry out studies on the intensification of the water purification process on contact clarifiers. Filtering bed with a positive charge was obtained by applying to the surface of grains of quartz sand the solution of coagulant aluminum sulphate with a concentration of 50 $\mathrm{mg} \cdot \mathrm{dm}^{-3}$. The work of contact clarifiers at modernization of quartz sand filtering bed occurs in 2 stages.

Stage 1 - modification of quartz sand filtering bed with a solution of aluminum sulfate for 1-6 minutes.

Stage 2 - water clarification in contact clarifiers by supplying source water from bottom to top. With that the contact coagulation occurring, in which the process of clarification carried out due to the contact of colloidal and suspended particles with the surface of the modified quarts sand.

The installation consists of two models of contact clarifiers made of plexiglas tubes in the form of cylinders with a diameter of $50 \mathrm{~mm}$ and a height of $1.5 \mathrm{~m}$. Transparent 
walls of the models made it possible to observe the behaviour of the filtering bed. In the models of contact clarifiers water supplied from the bottom up. The filtering bed height of the contact clarifiers was assumed to be $0.7 \mathrm{~m}$. For filtering bed of quartz sand with an equivalent diameter of $0.9-1.1 \mathrm{~mm}$ was used; the height of the quartz sand bed is $0.5 \mathrm{~m}$; inhomogeneity filtering bed factor of 2.5 . The thickness of the supporting gravel beds was $0.2 \mathrm{~m}$. The filtering rate did not exceed $0.5 \mathrm{~m} \cdot \mathrm{h}^{-1}$. The washing time was 3-5 min with a backwash velocity of $15-22 \mathrm{~m} \cdot \mathrm{h}^{-1}$. The duration of the filter cycle was 20 min.

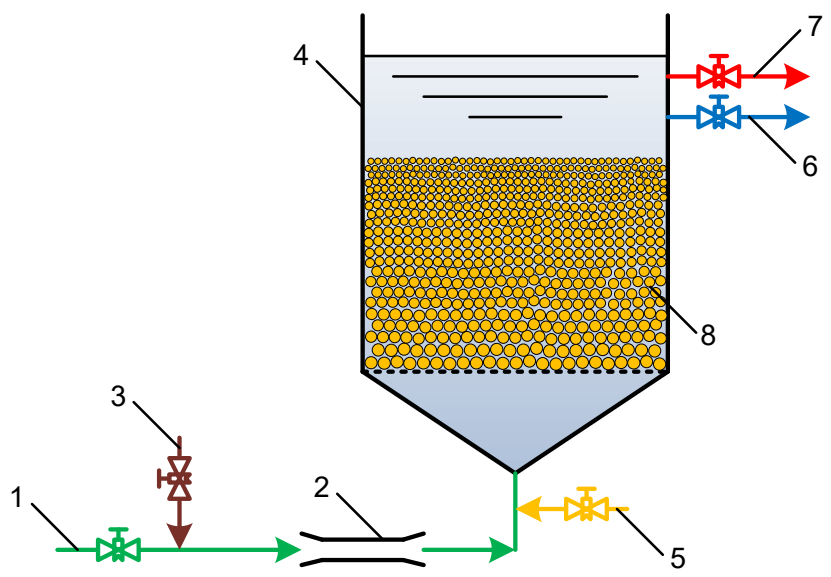

Fig. 1. Scheme of a laboratory installation; $1=$ pipeline of initial water supply; $2=$ collar mixer; $3=$ pipeline of supply the solution of aluminum sulphate; $4=$ contact clarifier; $5=$ pipeline of supply the washing water; $6=$ pipeline of filtrate remove; $7=$ pipeline of washing water remove; $8=$ quartz sand filtering bed; source: own elaboration

The main technological criterion for the effectiveness of the use the modified filtering bed of the contact clarifier considered the residual content of suspended solids in clarified water, as well as its colour of water, because such indicators are the main, characterizing the work of water treatment plants as a whole, and their individual structures, for example, contact clarifiers. During the experiments, the residual content of suspended solids in the filtrate determined by the weight method, in a number of cases it is possible to determine by measuring the light attenuation coefficient using a photoelectric colorimeter.

The resulting effect of modifying the filtering bed of the contact clarifier is determined towards:

$$
E_{e f}=100 \cdot D_{0} / D_{m}-100
$$

Where: $E_{e f}=$ modification effect $(\%) ; D_{0}=$ residual content of suspended solids $\left(\mathrm{mg} \cdot \mathrm{dm}^{-3}\right)$ or colour (degrees platinum cobalt scale) of water in the clarified water (the optical density of the suspended solids in sample) at conventional filtration; $D_{m}=$ residual content of suspended solids $\left(\mathrm{mg} \cdot \mathrm{dm}^{-3}\right)$ or colour (degrees platinum cobalt scale) of water in the clarified water with modifying the filtering bed with a solution of aluminum sulphate.

The effectiveness of modifying of quartz sand bed on the duration of the filter cycle $E_{f c}$ determined by the formula:

$$
E_{f c}=100 \cdot F_{m} / F_{0}-100
$$

Where: $F_{0}=$ the duration of the filter cycle with normal filtering $(\mathrm{min}) ; F_{m}=$ the duration of the filter cycle at modifying the filtering bed by the solution of aluminum sulphate.

\section{RESULTS AND DISCUSSIONS}

The main indicator characterizing the electrical properties of beds, soils, suspensions, was adopted electrokinetic potential. Determination $\zeta$-potential of the filtering bed determined by the percolation potential method, which, according to the studies of VEITSER et al. [1974] and DUSHKIN et al. [2012] depends on the dose of the coagulant and the type of filtering bed.

The modification of the quartz sand bed was performed with solution of aluminum sulphate with a dose of $50 \mathrm{mg} \cdot \mathrm{dm}^{-3}$, counting on $\mathrm{Al}_{2} \mathrm{O}_{3}$ for $5 \mathrm{~min}$. Then the solution removed by pipeline of washing water remove and used in water purification process. More details the methodic of experiment describes in paper by DUSHKIN [2012].

The following basic questions studied:

- influence of the time of processing of quartz sand bed by the solution of aluminum sulphate coagulant on the duration of filter cycle and the quality of water purification; - filter cycles number of use the modified filtering bed.

The effect of the dose of solution of aluminum sulphate coagulant on the $\zeta$-potential of the filtering bed during its modification is show in Table 1. The last column of Table 1 shows the value of the confidence potential, which shows good reproducibility of the experimental data within the confidence interval, calculated on the base of four experiments performed in parallel with a reliability of 0.95 . Figure 2 shows the influence of the modification time of the contact clarifier on the increase of the filter cycle duration in comparison with the duration of the filter cycle of the contact clarifier without modification of the filtering bed.

Table 1. Effect of a dose of coagulant solution on the $\zeta$-potential

\begin{tabular}{|c|c|c|c|c|c|c|}
\hline \multirow{2}{*}{$\begin{array}{c}\text { Name of } \\
\text { bed }\end{array}$} & \multicolumn{5}{|c|}{$\begin{array}{l}\zeta \text {-potential of filtering bed }(\mathrm{mV}) \text { at the dose } \\
\text { of reagent, calculated on } \mathrm{Al}_{2} \mathrm{O}_{3} \text { in } \mathrm{mg} \cdot \mathrm{dm}^{-3}\end{array}$} & \multirow{2}{*}{$\begin{array}{l}\text { The value of the } \\
\text { confidence } \\
\text { interval } a(\mathrm{mV}) \\
\gamma=0.95 ; n=4\end{array}$} \\
\hline & 25.0 & 40.0 & 50.0 & 60.0 & 75.0 & \\
\hline $\begin{array}{l}\text { Quartz } \\
\text { sand }\end{array}$ & 27.2 & 29.6 & 34.6 & 30.5 & 29.2 & $\begin{array}{c}a=34.6 \\
33.4<a<35.9\end{array}$ \\
\hline Haydite & 24.1 & 27.3 & 30.5 & 27.6 & 26.3 & $\begin{aligned} a & =30.5 \\
28.3 & <a<31.6\end{aligned}$ \\
\hline $\begin{array}{l}\text { «Burnt } \\
\text { breed» }\end{array}$ & 20.2 & 22.5 & 29.1 & 25.4 & 24.1 & $\begin{aligned} a & =29.1 \\
28.2 & <a<30.4\end{aligned}$ \\
\hline
\end{tabular}
at different doses during the modification of the filtering bed

Explanations: $\gamma=$ reliability, $n=$ number of parallel experiments. Source: own study.

Established that the $\zeta$-potential of the filtering bed depends on the dose of the reagent and the type of filtering material; the best results were obtained at studying the quartz sand filtering bed. Assessment of the results reliability of the performed experiments (Tab. 1) shows good reproducibility of the experimental data within the confidence interval calculated based on four parallel-performed experiments. 


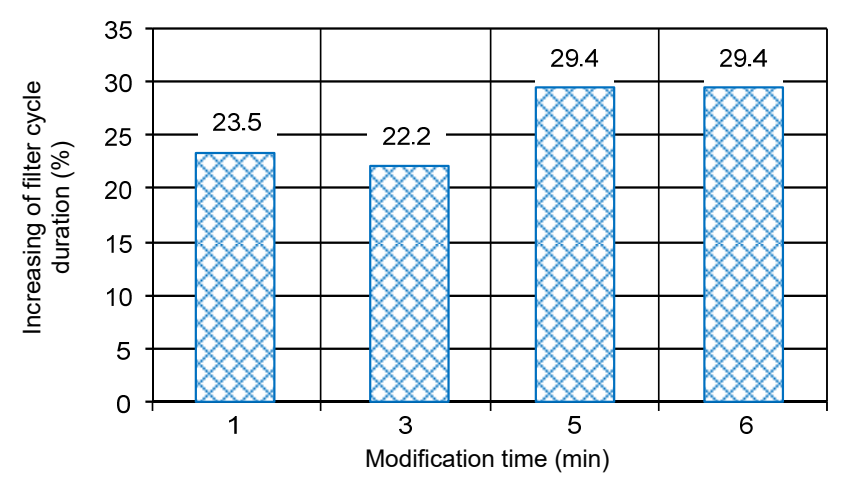

Fig. 2. Influence of the duration of filtering bed modification of contact clarifiers to the increasing the duration of the filter cycle; source: own study

The influence of time modification of the quartz sand bed of contact clarifiers to the duration of the filter cycle is show in Table 2.

Table 2. Influence of the time modification on the duration of the filter cycle

\begin{tabular}{|c|c|c|}
\hline \multirow{2}{*}{$\begin{array}{c}\text { No. of filter } \\
\text { cycle series }\end{array}$} & \multicolumn{2}{|c|}{ Duration of filter cycle (min) } \\
\cline { 2 - 3 } & conventional filtration & at modified bed \\
\hline F-1 & 170 & $210(1)$ \\
\hline F-2 & 180 & $220(3)$ \\
\hline F-3 & 170 & $220(5)$ \\
\hline F-4 & 170 & $220(6)$ \\
\hline
\end{tabular}

Explanation: in brackets is given time of bed modification. Source: own study.

The performed studies allow us to conclude that the duration of the filter cycle depends on a certain extent on the time of modification of the filtering bed.

The modification of the quartz sand filtering bed of the contact clarifier with the coagulant aluminum sulphate solution allows improving the quality of the filtrate, which confirmed by the data given in Tables 3 and 4 . Figure 3 shows the influence of the duration of the modification of the filtering bed of contact clarifier to the reduction of turbidity and colouration of the filtrate compared with the values of these indicators without modifying the filtering bed. In this case, the use of modified quartz sand bed allows improving the quality of clarification of water in contact clarifiers. So for the modified filtering bed, in comparison with the usual, it was possible to reduce the turbidity of the filtrate from $2.46-2.18 \mathrm{mg} \cdot \mathrm{dm}^{-3}$ to $1.52-1.41$ $\mathrm{mg} \cdot \mathrm{dm}^{-3}$, that is, on average $60 \%$. The colour of water in the filtrate decreases to $26.3-30.1 \%$.

Table 3. Influence of the modification time on the turbidity of the filtrate

\begin{tabular}{|c|c|c|}
\hline \multirow{2}{*}{$\begin{array}{c}\text { No. of filter } \\
\text { cycle series }\end{array}$} & \multicolumn{2}{|c|}{ Turbidity of filtrate $\left(\mathrm{mg} \cdot \mathrm{dm}^{-3}\right)$} \\
\cline { 2 - 3 } & conventional filtration & at modified bed \\
\hline F-1 & 2.46 & $1.52(1)$ \\
\hline F-2 & 2.09 & $1.35(3)$ \\
\hline F-3 & 2.33 & $1.41(5)$ \\
\hline F-4 & 2.18 & $1.37(6)$ \\
\hline
\end{tabular}

Explanation as in Tab. 2.

Source: own study.
Table 4. Influence of the modification time on the colour of the filtrate

\begin{tabular}{|c|c|c|}
\hline \multirow{2}{*}{$\begin{array}{c}\text { No. of filter } \\
\text { cycle series }\end{array}$} & \multicolumn{2}{|c|}{ Colour of water of filtrate (degree PCS) } \\
\cline { 2 - 3 } & conventional filtration & at modified bed \\
\hline F-1 & 27 & $21(1)$ \\
\hline F-2 & 24 & $19(3)$ \\
\hline F-3 & 25 & $18(5)$ \\
\hline F-4 & 26 & $20(6)$ \\
\hline
\end{tabular}

Explanation as in Tab. 2.

Source: own study.



Fig. 3. Influence of the modification duration of contact clarifiers filtering bed to the reduction of turbidity and colour of the filtrate; source: own study

Thus, it can be argued that the use of a modified filtering bed makes it possible to improve the quality of the filtrate, both in turbidity and in colour of water.

The modification of the quartz sand filtering bed of the contact clarifiers with a coagulant solution of aluminum sulphate allows it to be used without reducing the quality of the filtrate, which is confirmed by the experimental data in Table 5. During conventional filtration, the washing of grains of filtering bed is carried out after 5-6 filter cycles, and with the modification is $8-9$ filter cycles.

Table 5. Influence of the frequency of use the modified filtering bed to the turbidity and colour of water of the filtrate

\begin{tabular}{|c|c|c|c|c|}
\hline \multirow{2}{*}{$\begin{array}{c}\text { No series } \\
\text { of filter } \\
\text { cycle }\end{array}$} & \multicolumn{2}{|c|}{$\begin{array}{c}\text { Turbidity of the filtrate } \\
\left(\mathrm{mg} \cdot \mathrm{dm}^{-3}\right)\end{array}$} & \multicolumn{2}{c|}{$\begin{array}{c}\text { Colour of water of filtrate } \\
\text { (degree PCS) }\end{array}$} \\
\cline { 2 - 5 } & $\begin{array}{c}\text { conventional } \\
\text { filtration }\end{array}$ & $\begin{array}{c}\text { at modified } \\
\text { bed }\end{array}$ & $\begin{array}{c}\text { conventional } \\
\text { filtration }\end{array}$ & $\begin{array}{c}\text { at modified } \\
\text { bed }\end{array}$ \\
\hline F-1 & 1.29 & 1.13 & 20 & 19 \\
\hline F-2 & 1.31 & 1.14 & 19 & 19 \\
\hline F-3 & 1.28 & 1.15 & 20 & 20 \\
\hline F-4 & 1.32 & 1.15 & 21 & 19 \\
\hline F-5 & 1.05 & 1.21 & 20 & 19 \\
\hline F-6 & 1.45 & 1.19 & 23 & 19 \\
\hline F-7 & - & 1.25 & - & 20 \\
\hline F-8 & - & 1.35 & - & 24 \\
\hline F-9 & - & 1.59 & - & washing \\
\hline
\end{tabular}

Source: own study.

It should be noted that according to study the criterion of the optimal filtering mode is the ratio between the duration of the protective action of the filtering bed $t_{\text {protect }}$ and 
the filter operating time until the moment of reaching the limiting head loss $t_{\text {pressure }}$ [MINTS, KASTALSKIY 1984]. Technologically and economically, the best mood is one in which $t_{\text {protect }}=t_{\text {pressure }}$ Nevertheless, from the side of sanitary reliability it is advisable to take the value $t_{\text {protect }} / t_{\text {pressure }}>1$, since in this case, during the all filter cycle, a high quality of the filtrate is guaranteed, increases the degree of sanitary reliability of buildings.

At modifying the quartz sand filtering bed of contact clarifiers increases the duration of the protective action of the filtering bed $t_{\text {protect }}$ and the time to achieve the limiting head loss $t_{\text {pressure}}$, which allows to intensify the process of water clarification.

\section{CONCLUSIONS}

1. Aluminum sulphate should be used as a coagulant, which is the most environmentally friendly reagent at purifying drinking water on contact clarifiers.

2 . If the grain of the filtering bed cover with a coagulant film of aluminum hydroxide or a film of a flocculants (for example polyacrylamide), the filtering bed acquire a positive charge.

3. Use of the modified filtering bed allows improving the quality of the filtrate, both in turbidity and in colour of water. The quality of the filtrate by turbidity increases by $54.8-65.2 \%$, and by colour of water by $26.3-38.8 \%$.

4. Experimental data show that the use of the modified filtering bed allows increasing the filter cycle by an average of $30 \%$ without deteriorating the quality of the filtrate, and thereby increasing the dirt-holding capacity of the filtering bed.

\section{REFERENCES}

Benrabah S., Attoui B., Hannouche M. 2016. Characterization of groundwater quality destined for drinking water supply of Khenchela city (eastern Algeria). Journal of Water and Land Development. No. 30 p. 13-20. DOI 10.1515/jwld2016-0016.

Bergel T., Szelag B., Woyciechowska O. 2017. Influence of a season on hourly and daily variations in water demand patterns in a rural water supply line case study. Journal of Water and Land Development. No. 34 p. 59-64. DOI 10.1515/jwld2017-0038.

DUSHKIN S.S. 2012. Metodologicheskiye aspekty provedeniya issledovaniy pri ispolzovanii aktivirovannykh rastvorov koagulyanta $\mathrm{v}$ protsesse ochistki vody [Methodological aspects of conducting studies using activated coagulant solutions in the process of water purification]. Komunalne hospodarstvo mist. Vol. 105 p. 320-334.

DushKin S.S., Blahodarna H.I., Kovalenko O.M., YevdoSHENKO V.V., HRES O.V. 2017. Sposib ochystky pryrodnykh i stichnykh vod [Method of surface water and wastewater treatment]. Patent of Ukraine. Patent specification UA 118596. IPC S02 F1/48. Appl. no. a 2017 02868. Date of filing 27.03.2017. Date of publ. 10.08.2017 (Bulletin No 15).

DushKIN S.S., BlahodaRna H.I., TyKhONIUK V.O. 2002. Sposib modyfikatsiyi filtruyuchoho zavantazhennya dlya osvitlennya pryrodnykh i stichnykh vod [Method of modification of filter loading for clarifying of surface and sewage waters]. Patent of Ukraine. Patent specification UA 45258. IPC S02 F1/48. Date of publ. 15.03.2002 (Bulletin No. 3).
Epoyan S., Karahiaur A., Volkov V., BabenKo S. 2018. Research into the influence of vertical drainage elements on the operational efficiency of rapid filters. Eastern-European Journal of Enterprise Technologies. Vol. 1. No. 10 (91) p. 62-69. DOI 10.15587/1729-4061.2018.123559.

EPOYAN S.M., DUSHKIN S.S. 2013. Snizhenie agregativnoy ustoychivosti kolloidnov primesi prirodnykh vod aktivirovannym rastvorom koagulyanta sulfata alyuminiya [Reduction of aggregative stability of colloidal impurity of surface waters by activated solution of aluminum sulphate coagulant]. MOTROL. Vol. 15. No. 5 p. 11-16.

Hammouri L., Al-Qinna M., Salahat M., Adamowski J., PRASHER S.O. 2015. Community based adaptation options for climate change impacts on water resources: The case of Jordan. Journal of Water and Land Development. No. 26 p. 3 17. DOI 10.1515/jwld-2015-0013.

JaWecki B., Pawęska K., Sobota M. 2017. Operating household wastewater treatment plants in the light of binding quality standards for wastewater discharged to water bodies or to soil. Journal of Water and Land Development. No. 32 p. 3139. DOI 10.1515/jwld-2017-0004.

Kulykov N.Y., NAIMANOV A.Ya., OMELCHENKO N.P., CHERNISHEV V.N. 2009. Teoreticheskie osnovy ochistki vody [Theoretical basis of water treatment]. Donetsk, Ukraine. Knowledge. ISBN 978-966-1571-22-7 pp. 298.

ŁABĘDZKI L. 2016. Actions and measures for mitigation drought and water scarcity in agriculture. Journal of Water and Land Development. No. 29 p. 3-10. DOI 10.1515/jwld-2016-0007.

Marzec M., PieńKo A., Gizińska-Górna M., PytKa A., JóźWIAKOWSKI K., SOSNOWSKA B., KAMIŃSKA A., LisTOSZ A. 2017. The use of carbonate-silica rock (opoka) to remove iron, manganese and indicator bacteria from groundwater. Journal of Water and Land Development. No. 34 p. 197-204. DOI 10.1515/jwld-2017-0054.

MinTs D.M., KASTALSKIY A.A. 1984. Podhotovka vody dlia pitevoho i promyshlennoho vodosnabzheniya [Preparation of water for drinking and industrial water supply]. Moscow. Vysshaya shkola pp. 386.

MŁYŃSKi D., ChMielOwsKi K., MŁYŃSKA A. 2016. Analysis of hydraulic load of a wastewater treatment plant in Jasło. Journal of Water and Land Development. No. 28 p. 61-67. DOI 10.1515/jwld-2016-0006.

ORLOV V., MARTYNOV S., KUNYTSKIY S. 2016. Energy saving in water treatment technologies with polystyrene foam filters. Journal of Water and Land Development. No. 31 p. 119-122. DOI 10.1515/jwld-2016-0042.

POLYAKOV V.L. 2011. The engineering calculation of filtering a suspension through a two-layer medium in linear kinetics of mass exchange. Journal of Water Chemistry and Technology. Vol. 33. No. 4 p. 367-380.

TAtari K., Smets B.F., AlbrechtSen H.-J. 2016. Depth investigation of rapid sand filters for drinking water production reveals strong stratification in nitrification biokinetic behavior. Water Research. Vol. 101 p. 402-410. DOI 10.1016/j.watres. 2016.04.073.

Vasylenko O.A., Hrabovskyi P.O., Larkina H.M., POlSHCHUK O.V., PROHULNYI V.I. 2010. Rekonstruktsiya i intensyfikatsiya sporud vodopostachannya ta vodovidvedennya. [Reconstruction and intensification of water supply and wastewater facilities]. Kyiv, Ukraine. Ukrgelioteh. ISBN 978966-2216-05-9 pp. 272.

Veitser Yu.Y., Kolobova Z.A., SAFonova H.M. 1974. Vliyaniye znaka elektricheskogo zaryada zagruzki i vzveshennykh veshchestv na protsess filtrovaniya [Impact of the electric charge sign of downloads and suspended solids for the filtration process]. Nauchnye trudy AKKh im. K.D. Pamfylova. No. 97 p. 33-42. 


\section{Stanislav S. DUSHKIN, Serhii MARTYNOV, Stanislav S. DUSHKIN}

Intensyfikacja funkcjonowania zbiornika kontaktowego do uzdatniania wody do picia

\section{STRESZCZENIE}

W pracy przedstawiono wyniki badań intensyfikacji procesu klarowania wody na urządzeniach kontaktowych ze złożem filtrującym z piasku kwarcowego, które zmodyfikowano roztworem koagulantu (siarczanu glinu). Modyfikację złoża przeprowadzono, aplikując roztwór koagulantu w różnych dawkach na powierzchnię ziaren złoża piaskowego. Potencjał elektrokinetyczny materiału filtrującego oznaczono metodą perkolacji.

Badano wpływ właściwości elektrycznych (wielkość i znak ładunku) samego złoża i cząstek zawiesiny w wodzie na proces filtracji. Materiał filtrujący (piasek kwarcowy) ma ujemny ładunek elektryczny. Kiedy ladunek elektryczny cząstek maleje, to znaczy, kiedy maleje potencjał $\zeta$, maleją siły odpychania i adhezja cząstek staje się możliwa. Oznacza to proces koagulacji koloidu. Siły wzajemnego przyciągania cząstek koloidalnych zaczynają dominować nad siłami elektrycznego odpychania, gdy potencjał $\zeta$ systemu jest mniejszy od $0,03 \mathrm{~V}$.

Modyfikacja złoża kwarcowego siarczanem glinu jako koagulantem zalecana w oczyszczaniu wody powierzchniowej umożliwia: intensyfikację procesu klarowania wody, ograniczenie zużycia odczynników o 25-30\% i jednocześne uzyskanie wody o wymaganej jakości, redukcję powierzchni niezbędnej dla urządzeń uzdatniających, a także zmniejszenie kosztów uzdatniania o $20-25 \%$.

Słowa kluczowe: filtracja wody, intensyfikacja oczyszczania, kontaktowe urządzenie klarujace, kwarcowe złoże filtracyjne, siarczan glinu, wody powierzchniowe 